\title{
New Emerging Treatment Options for Advanced Basal Cell Carcinoma and Squamous Cell Carcinoma
}

\author{
Alessia Villani · Luca Potestio · Gabriella Fabbrocini · Massimiliano Scalvenzi
}

Received: November 4, 2021 / Accepted: January 10, 2022 / Published online: January 28, 2022

(C) The Author(s) 2022

\begin{abstract}
Non-melanoma skin cancers, also known as keratinocyte tumors, have an increasing incidence worldwide, with basal cell carcinoma and squamous cell carcinoma being the most represented ones. Although surgery represents the gold-standard treatment for both tumors, some cases can progress to an advanced or a metastatic state and targeted therapy is required. Hedgehog signaling pathway has an important role in the development of basal cell carcinoma, and its inhibition is the key to new treatment options available for the treatment of locally advanced and metastatic basal cell carcinoma. Cutaneous squamous cell carcinoma is the second most frequent malignant skin cancer; when presenting in advanced or metastatic stage, alternative treatments are required; cemiplimab is a human monoclonal antibody directed against programmed cell death-1 receptor that acts by blocking T-cell inactivation and is the first drug approved for the treatment of adult patients with metastatic or locally advanced
\end{abstract}

Alessia Villani and Luca Potestio equally contributed to the article.

A. Villani $(\bowtie) \cdot$ L. Potestio $\cdot$ G. Fabbrocini .

M. Scalvenzi

Section of Dermatology, Department of Clinical

Medicine and Surgery, University of Naples Federico

II, Via Pansini 5, 80131 Napoli, Italy

e-mail: ali.vil@hotmail.it cutaneous squamous cell carcinoma. Studies evaluating pembrolizumab, ipilimumab and nivolumab as alternative treatments for advanced squamous cell carcinoma are still underway. Objective of this review is to analyze and discuss the novel therapies for advanced basal cell carcinoma and squamous cell carcinoma to obtain a sharper perspective of the available treatment options.

Keywords: Basal cell carcinoma; Squamous cell carcinoma; Hedgehog inhibitor; Vismodegib; Sonidegib; Cemiplimab

\section{Key Summary Points}

Why carry out this study?

Surgical excision remains the main recommended therapy for easy-to-treat basal cell carcinoma (BCC), while difficult-to-treat BCC, including locally advanced BCC (laBCC) and metastatic BCC (mBCC), still represent the real challenge

The majority of cutaneous squamous cell carcinoma (cSCC)s are successfully treated with surgical excision and radiation therapy. However, treating metastatic cSCC and locally advanced cSCC (lacSCC) remains the main goal of clinical practice 
New emerging treatment options for advanced forms of BCC and squamous cell carcinoma (SCC) are required to offer non-invasive alternatives to patients not eligible for conventional treatments

\section{What was learned from the study?}

Hedgehog inhibitors (HHIs) are promising alternative treatments for patients with advanced basal cell carcinomas; vismodegib and sonidegib, two oral smoothened (SMO) antagonists, have already been approved for the treatment of adult patients with advanced basal cell carcinoma

Currently, US Food and Drug Administration (FDA) has granted Orphan Drug and Breakthrough Therapy Designation for topical patidegib gel formulation in patients with basal cell carcinoma nevus syndrome, also known as Gorlin syndrome

Cemiplimab has been approved by the European Medicines Agency (EMA) and Food and Drug Administration (FDA) for the treatment of adult patients with metastatic or locally advanced cutaneous squamous cell carcinoma, not eligible for surgery or radiotherapy, and for adult patients with locally advanced or metastatic BCC intolerant to a $\mathrm{HH}$ pathway inhibitor

\section{INTRODUCTION}

Non-melanoma skin cancers, also known as keratinocyte carcinomas (KC)s, are the most frequent tumors in the Western world $[1,2]$. In particular, basal cell carcinoma (BCC) accounts for $80 \%$ of KCs, with cutaneous squamous cell carcinoma (cSCC) representing the remaining $20 \%$ [2].

BCC incidence is increasing worldwide with a lifetime risk of $20-30 \%$ [3]. They present as asymptomatic, enlarging and often bleeding lesions usually located in sun-damaged areas [4].

Conversely, cSCC has a rising worldwide lifetime risk of $9-14 \%$ for men and $4-9 \%$ for women, respectively [5]. Solitary red scaly plaques or nodules located in sun-exposed areas are the most common clinical presentation of cSCC [6].

While cSCC can develop metastasis in 3-7\% of cases, BCC metastasis are rare [2].

Regarding risk factors, most of them are shared: chronic UV exposure, tanning bed use, ionizing radiations, fair skin, age $>70$ years, immunosuppression and chronic inflammation are the most common ones [2].

Unique risk factors include blistering sunburns and some genetic alterations (basal cell nevus syndrome, telomeric function gene variants) for BCC and human papilloma virus infection, immunosuppressive drugs, arsenic and genetic diseases (xeroderma pigmentosum, oculocutaneous albinism) for CSCC, respectively $[2,4,7,8]$.

Surgical excision represents the gold-standard treatment for both tumors [9]. However, this approach depends on tumor characteristics, such as stage, histopathological subtype, location and patients' comorbidities [10-12]. Surgical excision, including Mohs micrographic surgery and destructive treatment (topical treatments such as imiquimod, 5-fluoruracil; cryotherapy, laser therapy, radiation therapy or photodynamic therapy) remain the main recommended therapies for easy-to-treat BCC. Difficult-to-treat BCC, including locally advanced BCC (laBCC) and metastatic BCC (mBCC), still represent the real challenge [13].

Most cSCCs are successfully treated with surgical excision, photodynamic therapy, laser treatment, cryosurgery and radiation therapy. However, treating metastatic cSCC (mcSCC) and locally advanced cSCC (lacSCC) remain the main goal of clinical practice [14].

Thus, new emerging treatment options for BCC and CSCC are required to offer non-invasive alternatives and a tailored-tail therapy to patients not eligible for conventional treatments such as surgery or radiation therapy. Objective of this review is to analyze and discuss the novel therapies for advanced BCCs and 
cSCCs to obtain a sharper perspective related to the available treatment options according to specific patients' characteristics.

\section{METHODS}

A search of the PubMed, Embase and clinicaltrials.gov databases was performed using the following research terms: "basal cell carcinoma," "cutaneous squamous cell carcinoma," "keratinocyte carcinoma," "vismodegib," "sonidegib," "patidegib," "taladegib," "cemiplimab" and "pembrolizumab". Reviews, metanalyses, clinical trials (CT), real-life studies (RLS), case reports and series were reviewed, and the most relevant articles were included. The assessment of treatment efficacy was made through overall survival (OS), progression-free survival (PFS), recurrence-free survival (RFS), disease-free survival (DFS), durable response rate (DRR) and overall response rate (ORR). Articles and trials regarding standard treatments, such as surgery or radiation therapy, used to treat KCs were excluded. This article is based on previously conducted studies and does not contain any studies with human participants or animals performed by any of the authors.

\section{NEW EMERGING THERAPIES FOR ADVANCED BCC}

\section{Basal Cell Carcinoma and Hedgehog Pathway Inhibition}

Hedgehog (HH) pathway, usually silenced in adults, has a key role in different aspects of cell life such as organogenesis, patterning, proliferation, survival and differentiation [15]. It was originally discovered in Drosophila. The $\mathrm{HH}$ signaling cascade could be stimulated by three different ligands that are involved in this pathway: Sonic hedgehog (SHH), Indian hedgehog and Desert hedgehog. However, SHH is widely expressed in human tissues [16]. These ligands bind to the receptor Patched-1 (PTCH), a membrane receptor localized on the surface of target cells, which normally acts by inhibiting Smoothened (SMO), another membrane protein, thus initiating the $\mathrm{HH}$ signaling cascade [17]. The inhibition of SMO is relieved, resulting in an aberrant activation of the cascade.

In this pathway, SMO has a key role; it acts by activating $\mathrm{HH}$ signaling cascade and leads to the activation of the transcription factors for glioma-associated oncogene homolog 1 (Gli1), which activates angiogenetic and target genes (Bcl-2, Cyclin-D1 and Myc) [17]. In absence of SHH ligand, $\mathrm{HH}$ cascade is inactive and $\mathrm{PTCH}$ inhibits SMO activity preventing Gli1-target gene transcription. The HH pathway is involved in cell growth regulation and differentiation during embryogenesis and is not active in adult tissues. The aberrant activation of $\mathrm{HH}$ pathway is characterized by an increased cell proliferation and survival, implicated in the pathogenesis of different solid tumors including BCC. Patients with Gorlin syndrome present a germline mutation (single hit) in PTCH gene that relieves SMO inhibition leading to the development of multiple BCCs along with other tumors. Approximately $90 \%$ of cases of sporadic BCCs, instead, present a somatic mutation causing loss of function (two hits) in PTCH gene [18]. Thus, targeting the $\mathrm{HH}$ pathway is the active principle of the new oral drugs for the treatment of advanced BCCs. The HH inhibitors act by binding to SMO, thus preventing Gli1 release and tumor growth. The HH pathway and role of $\mathrm{HH}$ inhibitors are represented in Fig. 1.

The main features in terms of efficacy and safety of the $\mathrm{HH}$ inhibitors are reported in Table 1.

\section{Vismodegib}

Vismodegib (Erivedge ${ }^{\circledR}$ ) is an oral, second-generation cyclopamine derivate that acts by binding to SMO, thus inhibiting the $\mathrm{HH}$ pathway [19]. It was approved in January 2012 by the Food and Drugs Administration (FDA) and in 2013 by the European Commission to treat patients aged $\geq 18$ years with laBCC and mBCC who present recurrence of BCC following surgery or radiation therapy or those who are not candidates for surgery or radiotherapy. The approved dosage is $150 \mathrm{mg}$ daily [19]. Vismodegib is controindicated in women who are either pregnant or breast-feeding because of its 
potential embryotoxicity, as $\mathrm{HH}$ signaling plays a key role in early embryogenesis.

Its efficacy and safety have been evaluated in phase I and phase II clinical trials [20-23]. The first phase I study including 33 patients presenting with advanced BCCs was conducted in 2009; all patients were treated with $150 \mathrm{mg}$ daily of oral vismodegib for a median duration of response of 12.8 months reporting an objective response rate (ORR) of 58\% [20]. The ORR includes the percentage of patients reporting complete and partial response to treatment. The approval of the drug was related to a phase II, single-arm, two-cohort, multicenter trial (ERIVANCE) [21]. A total of 104 patients, divided in two cohorts (laBCC and mBCC) and receiving vismodegib $150 \mathrm{mg}$ daily, were included in the study. The primary endpoint was the ORR, defined as $\geq 30 \%$ tumor size reduction or complete resolution of tumor ulceration in laBCC and as $\geq 30 \%$ decrease in sum of longest diameter of target lesions for mBCC. The laBCC group $(n=63)$ reported an ORR of $43 \%(95 \%$ CI $31-56)$, while, the mBCC group $(n=33)$ reported an ORR of $30 \%$ (95\% CI 16-48) according to the efficacy analysis by independent review. ORRs of $60 \%$ and $46 \%$ for laBCC group and mBCC group, respectively, were reported by the investigator-assessed efficacy analysis.
Regarding drug-related adverse event (AE)s, all patients experienced at least one $\mathrm{AE}$, with muscle spasms, alopecia and dysgeusia being present in $71.2 \%, 66.3 \%$ and $55.8 \%$ of cases, respectively. Regarding severe AEs (grade $\geq 3$ ), weight decrease $(8.7 \%)$ and muscle spasms were the most frequently reported. Eight patients experienced grade $5 \mathrm{AEs}$, but the investigator did not consider any of the deaths related to the treatment. The 39-month follow-up confirmed the positive results, reporting an ORR of $60.3 \%$ and $48.5 \%$ for the laBCC and mBCC group, respectively. Vismodegib efficacy was also assessed by an expanded access study conducted on 119 patients with either laBCCs and mBCCs treated for a median duration of 5.5 months; $46.4 \%$ for the laBCC group and $30.8 \%$ for mBCC group were the ORRs reported [22]. Later, the STEVIE trial, a single-arm multicenter study, confirmed vismodegib efficacy on a larger cohort of patients (1215 patients; 1119 with laBCC and 96 with mBCC); in particular, an ORR of $69 \%$ (95\% CI 66-71) and an ORR of 37\% (95\% CI 27-48) were reported in the laBCC and mBCC group, respectively [23]. The safety profile confirmed what was reported in previous trials; the occurrence of treatment-emergent adverse events (TEAEs) per 100 patient-years of exposure showed higher rates during the first

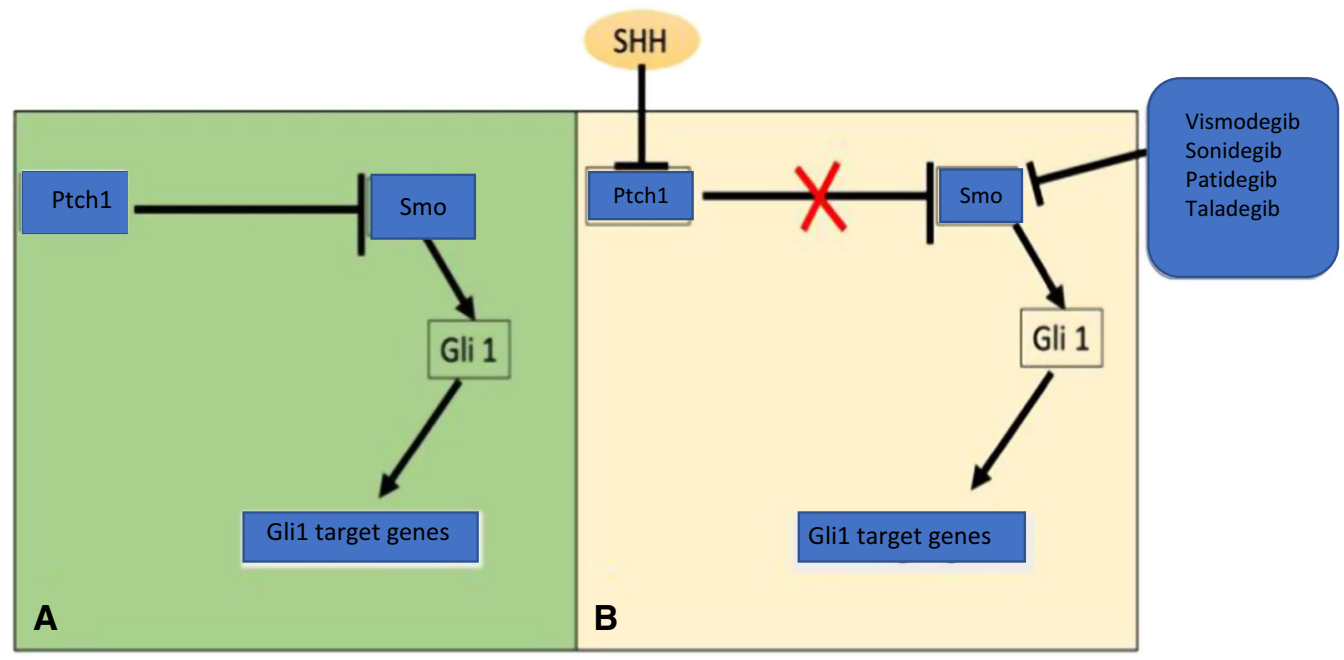

Fig. 1 A Normal Hedgehog pathway. B Dysregulated Hedgehog pathway with mechanism of action of investigated Hedgehog inhibitors. Pthcl Patched-1, Smo
Smoothened, Gli1 glioma-associated oncogene homolog 1, SHH Sonic Hedgehog 
Table 1 Main features of the Sonic Hedgehog pathway inhibitors in clinical trials

\begin{tabular}{|c|c|c|c|c|c|c|c|}
\hline Drug & Dosage & Tumor & Study & Patients & TTR & ORR & $\mathbf{A E}$ \\
\hline $\begin{array}{l}\text { Vismodegib } \\
{[20]}\end{array}$ & $\begin{array}{l}\text { Oral } 150 \mathrm{mg} \\
\text { QD }\end{array}$ & $\mathrm{BCC}$ & Phase I & 33 & NR & $58 \%$ & NR \\
\hline $\begin{array}{l}\text { Vismodegib } \\
{[21]}\end{array}$ & $\begin{array}{l}\text { Oral } 150 \mathrm{mg} \\
\text { QD }\end{array}$ & $\mathrm{BCC}$ & ERIVANCE & $\begin{array}{c}\text { Total: } 104 \\
\text { mBCC: } 33 \\
(31.7 \%) \\
\text { laBCC: } 63 \\
(60.6 \%)\end{array}$ & $\begin{array}{l}\text { mBCC: } \\
57 \text { days } \\
\text { laBCC: } \\
140 \text { days }\end{array}$ & $\begin{array}{l}\text { Total: } 53 \\
\quad(51.0 \%) \\
\text { mBCC: } 30 \% \\
\text { laBCC: } 43 \%\end{array}$ & $\begin{array}{l}\text { Muscle spasms } \\
\quad(74,71.2 \%) \\
\text { Alopecia (69, } \\
66.3 \%) \\
\text { Dysgeusia (58, } \\
55.8 \%)\end{array}$ \\
\hline $\begin{array}{l}\text { Vismodegib } \\
{[23]}\end{array}$ & $\begin{array}{l}\text { Oral } 150 \mathrm{mg} \\
\text { QD }\end{array}$ & $\mathrm{BCC}$ & STEVIE & $\begin{array}{l}\text { Total: } 1215 \\
\text { mBCC: } 96 \\
(7.9 \%) \\
\text { laBCC } 1119 \\
(92.1 \%)\end{array}$ & 3.7 months & $\begin{array}{l}\text { Total } 769 \\
(66.2 \%) \\
\text { mBCC: } 31 \\
(36.9 \%) \\
\text { laBCC: } 738 \\
(68.5 \%)\end{array}$ & $\begin{array}{c}\text { Muscle spasms } \\
793(65.3 \%) \\
\text { Alopecia } 732 \\
(60.2 \%) \\
\text { Dysgeusia } 647 \\
(53.3 \%)\end{array}$ \\
\hline $\begin{array}{l}\text { Sonidegib } \\
\text { [28] }\end{array}$ & $\begin{array}{l}\text { Oral } 200 \mathrm{mg} \\
\text { QD }\end{array}$ & $\mathrm{BCC}$ & BOLD & $\begin{array}{l}\text { Total: } 79 \\
\text { mBCC: } 13 \\
(16.5 \%) \\
\text { laBCC: } 66 \\
(83.5 \%)\end{array}$ & $\begin{array}{l}\text { mBCC: } \\
4.6 \text { months } \\
\text { laBCC: } \\
3.8 \text { months }\end{array}$ & $36 \%$ & $\begin{array}{l}\text { Muscle spasms } 39 \\
\quad(49.4 \%) \\
\text { Alopecia } 34 \\
(43.0 \%) \\
\text { Dysgeusia } 30 \\
(38.0 \%)\end{array}$ \\
\hline & $\begin{array}{l}\text { Oral } 800 \mathrm{mg} \\
\text { QD }\end{array}$ & $\mathrm{BCC}$ & BOLD & $\begin{array}{l}\text { Total: } 151 \\
\text { mBCC: } 23 \\
(15.2 \%) \\
\text { laBCC: } 128 \\
(84.8 \%)\end{array}$ & $\begin{array}{l}\text { mBCC: } \\
1.0 \text { months } \\
\text { laBCC: } \\
3.7 \text { months }\end{array}$ & $34 \%$ & $\begin{array}{c}\text { Muscle spasms } \\
100(66.2 \%) \\
\text { Dysgeusia } 89 \\
(58.9 \%) \\
\text { Alopecia } 83 \\
(55.0 \%)\end{array}$ \\
\hline $\begin{array}{l}\text { Patidegib } \\
\text { [32] }\end{array}$ & $\begin{array}{l}\text { Oral } \geq 130 \mathrm{mg} \\
\text { QD }\end{array}$ & $\mathrm{BCC}$ & Phase I & $\begin{array}{l}\text { Total: } 94 \\
\text { BCC: } 39\end{array}$ & NR & $20.5 \%$ & $\begin{array}{l}\text { Fatigue } 51 \\
\quad(54.3 \%) \\
\text { Alopecia } 36 \\
\quad(38.3 \%) \\
\text { Muscle spasms } 22 \\
(23.4 \%)\end{array}$ \\
\hline $\begin{array}{l}\text { Patidegib } \\
\text { [36] }\end{array}$ & $\begin{array}{l}\text { Topic } 2 \% \text { BD } \\
\text { Topic } 4 \% \text { BD }\end{array}$ & $\begin{array}{l}\text { BCC } \\
\text { BCC }\end{array}$ & $\begin{array}{l}\text { Phase II } \\
\text { Phase II }\end{array}$ & 6 & $\begin{array}{l}\text { NR } \\
\text { NR }\end{array}$ & NR & $\begin{array}{l}\text { None } \\
\text { None }\end{array}$ \\
\hline $\begin{array}{c}\text { Patidegib } \\
\text { [37] }\end{array}$ & Topic 2\% BD & BCC & Phase III & 36 & NR & NR & None \\
\hline
\end{tabular}


Table 1 continued

\begin{tabular}{|c|c|c|c|c|c|c|c|}
\hline Drug & Dosage & Tumor & Study & Patients & TTR & ORR & $\mathbf{A E}$ \\
\hline $\begin{array}{c}\text { Taladegib } \\
{[38]}\end{array}$ & $\begin{array}{l}\text { Oral } \\
50-1000 \mathrm{mg} \\
\text { QD }\end{array}$ & BCC & Phase I & $\begin{array}{r}\text { Total: } 84 \\
\text { BCC: } 47 \\
(56.0 \%)\end{array}$ & NR & $46.8 \%$ & $\begin{array}{c}\text { Dysgeusia } 41 \\
(48.8 \%) \\
\text { Fatigue } 37 \\
(44.0 \%) \\
\text { Nausea } 36 \\
(42.9 \%)\end{array}$ \\
\hline \multirow{3}{*}{$\begin{array}{c}\text { Taladegib } \\
{[39]}\end{array}$} & Oral $100 \mathrm{mg}$ & $\mathrm{BCC}$ & Phase I & 3 & NR & NR & Dysgeusia 3 \\
\hline & Oral $200 \mathrm{mg}$ & BCC & Phase I & 3 & NR & NR & $\begin{array}{l}\text { Dysgeusia } 2 \\
\text { Decreased } \\
\text { appetite } 1\end{array}$ \\
\hline & Oral $400 \mathrm{mg}$ & BCC & Phase I & 13 & NR & NR & $\begin{array}{l}\text { Decreased } \\
\text { appetite } 11 \\
\text { Fatigue } 9 \\
\text { Nausea } 9\end{array}$ \\
\hline
\end{tabular}

$T T R$ Time to response, $O R R$ objective response ratio, $A E$ adverse event, $Q D$ once daily, $B C C$ basal cell carcinoma, $m B C C$ metastatic basal cell carcinoma, laBCC locally advanced basal cell carcinoma, $W$ week, $B D$ twice daily

year of treatment, thus suggesting no trend toward new TEAEs or grade 3 TEAEs as treatment duration increased. Moreover, vismodegib showed promising results in terms of efficacy and safety also when administered at a longintermittent dosing regimen [24].

\section{Sonidegib}

Sonidegib (LDE-225) is the second oral $\mathrm{HH}$ inhibitor approved for the treatment of adult patients with locally advanced BCC not eligible for curative surgery or radiation therapy. It was approved in July 2015 by the FDA under the trade name of Odomzo ${ }^{\circledR}$ and in August 2015 by the European Commission at the approved dosage of $200 \mathrm{mg}$ daily [25]. Efficacy and safety of sonidegib have been evaluated in phase I and II clinical trials $[26,27]$. The approval of the drug was based on the pivotal phase II multicenter study (BOLT) including 230 patients with laBCC and mBCC [28]. Patients were randomly divided into two groups: one receiving sonidegib at a dosage of $200 \mathrm{mg} /$ daily $(n=79)$ and the other receiving $800 \mathrm{mg}$ sonidegib daily $(n=151)$ with treatment continued until progressive disease, intolerable toxicity, withdrawal of consent or death.

The median follow-up was 13.9 months. In the primary efficacy analysis, an objective response was observed in 36\% (95\% CI 24-50) and $34 \%$ (95\% CI 25-43) of patients receiving $200 \mathrm{mg}$ and $800 \mathrm{mg}$ sonidegib, respectively. Twenty-two percent of patients receiving $200 \mathrm{mg}$ sonidegib and $54 \%$ of patients receiving $800 \mathrm{mg}$ discontinued treatment. Ten percent of patients experienced mild-grade treatment-related adverse events (grade 1-2), including muscle spasms (49\%), alopecia (43\%), dysgeusia (38\%), nausea (33\%), raised blood creatine kinase (CK) levels (29\%), fatigue (29\%), decreased weight (27\%), diarrhea (24\%), decreased appetite (19\%), myalgia (19\%), headache (15\%) and arthralgia (13\%). The 30\% of patients receiving sonidegib $200 \mathrm{mg}$ once daily reported increased CK $(4 \%$ grade $3 ; 3 \%$ grade 4$)$, increased lipase (5\%; all grade 3$)$, 
hypertension, asthenia and muscle spasms (all $3 \%$; all grade 3). Secondary malignancies were also reported in $6 \%$ of patients. No deaths due to toxicity were reported. The 12 - and 18-month follow-up confirmed sonidegib efficacy, and at the 30-month analysis, patients with laBCC and mBCC treated at the approved dosage of $200 \mathrm{mg}$ daily reported an ORR of $71.2 \%$ and $33 \%$, respectively, with a median duration of response of 15.7 months in laBCC and 18.1 months in mBCC patients $[29,30]$. At the 42-month analysis of the BOLT trial, Dummer et al. confirmed sonidegib's long-term efficacy [31].

\section{Patidegib}

Patidegib, also known as saridegib or IPI-926, is a semysinthetic $\mathrm{HH}$ pathway inhibitor deriving from cyclopamine that selectively antagonizes the $\mathrm{HH}$ cascade by binding Smoothened receptor.

Jimeno et al. [32] conducted the first in-human phase I study, including 94 patients with advanced solid tumors treated with oral patidegib at different dosing regimen (ranging from 20 to $210 \mathrm{mg}$ daily), to evaluate the pharmacokinetic profile, antitumor activity and doselimiting toxicity. Thirty-nine patients had advanced BCC (5 were affected by Gorlin's syndrome); of these, 28 patients were considered evaluable, having received more than one dose and being vismodegib-naïve. Patidegib showed anti-tumor activity in patients who were vismodegib-naïve; complete response (CR) and partial response (PR) were assessed in two and six patients, respectively; however, two patients receiving patidegib after vismodegib treatment did not experience any objective response. Drug-related adverse events, including muscle spasms, fatigue, nausea and hair loss, were reported.

A Phase 2 double-blind, randomized, placebo-controlled trial evaluated the efficacy of patidegib gel compared to vehicle gel in 17 patients affected by Gorlin syndrome [33]. In particular, five patients were treated with placebo, six with patidegib $2 \%$ and six with patidegib $4 \%$ gel twice daily up to 26 weeks of treatment. Main objective of the study was to assess the change in BCC diameter, followed by the prevention of new BCCs. BCC $>5 \mathrm{~mm}$ in diameter of the face and $>9 \mathrm{~mm}$ in the other sites were defined as surgical eligible basal cell carcinoma (SEBs). At week 26, 2\% and 4\% topical patidegib caused tumor CR in $25 \%$ of SEBs ( $p=0.02$ compared with placebo), and a new facial BCC was assessed in 2/12 (16\%) patidegib-treated patients ( $p=0.02$ for prevention). Moreover, patidegib 2\% gel showed a reduction of $51.29 \%$ in the number of tumors from baseline, while patidegib $4 \%$ gel shown a reduction of $26.63 \%$, demonstrating a better clinical effect at $2 \%$ vs. $4 \%$ concentration.

Safety of topical patidegib was also confirmed; no muscle cramps, hair loss and taste loss were reported [33]. Currently, the US Food and Drug Administration (FDA) has granted Orphan Drug and Breakthrough Therapy Designation for topical patidegib in patients with basal cell carcinoma nevus syndrome, also known as Gorlin syndrome [35].

Another Phase II, double-blind and placebocontrolled clinical trial on 36 patients with sporadic nodular BCC treated with patidegib $2 \%$ once daily $(n=6), 2 \%$ twice daily $(n=6), 4 \%$ once daily $(n=6), 4 \%$ twice daily $(n=6)$ or placebo $(n=12)$ for 12 weeks confirmed topical patidegib efficacy and tolerability and compared the $2 \%$ and $4 \%$ patidegib gel formulations by evaluating adverse events and molecular efficacy (Gli1 mRNA level). Results showed that patidegib $2 \%$ gel has higher clinical and molecular efficacy than $4 \%$ gel [36]. Phase III trials (NCT04155190) and (NCT03703310), evaluating patidegib topical gel $2 \%$ efficacy in patients with Gorlin syndrome and with sporadic BCCs, are ongoing [37].

\section{Taladegib}

Taladegib, also known as LY2940680, is an anthranilamide derivative currently under study. It is a second-generation $\mathrm{HH}$ inhibitor acting by inhibiting SMO-receptor. A Phase I study, including 84 patients with advanced solid tumors, treated with different dosages (from 50 to $1000 \mathrm{mg}$ ) of taladegib once daily, showed its efficacy in treating patients with advanced BCC who had previously received Hedgehog inhibitor or not [38]. Of all the patients, 47 had BCC. Among these, a CR was 
assessed in $5(6.0 \%)$ patients and PR in 17 (20.2\%). The most common AEs reported were dysgeusia $(41,48.8 \%)$ followed by fatigue (37, $44.0 \%)$, nausea $(36,42.9 \%)$ and muscle spasms $(34,40.5 \%)$ [38].

Another Phase I study including 19 Japanese patients with advanced solid tumors showed that taladegib should be used at doses of $100 \mathrm{mg}$ or $200 \mathrm{mg}$ in this population, not at the global recommended dosage of $400 \mathrm{mg}$. The main $\mathrm{AE}$ reported was dysgeusia $(13 / 19,68.4 \%)$ followed by decreased appetite $(12 / 19,63.2 \%)$, nausea $(9 /$ $19,47.4 \%)$, fatigue $(9 / 19,47.4 \%)$ and vomiting $(6 / 19,31.6 \%)$. However, no data on efficacy of taladegib in BCC were evaluated from this study [39]. Currently, there are different trials investigating the use of taladegib in several tumors such as small-cell lung cancer, medulloblastoma and gastroesophageal adenocarcinoma [40].

\section{Immune Checkpoint Inhibitors for Cutaneous SCC}

The immune system plays a key role in the development of KC [2]. In particular, most cSCCs with high mutation rates are strongly associated with immunosuppression [41], and the high expression of Programmed-Death Ligand-1 (PD-L1) and Programmed-Death (PD1) receptor has been assessed in these tumors [42]. Thus, targeting the PD-L1/PD-1 axis to avoid the cancer immune evasion is the rationale for developing treatments that have emerged in recent years.

The main features in terms of safety and effectiveness of the immune checkpoint inhibitors are reported in Table 2 .

\section{Cemiplimab}

Cemiplimab (LIBTAYO ${ }^{\circledR}$ ) is a human monoclonal antibody that acts by targeting PD-1, a membrane receptor which is expressed on activated $\mathrm{T}$ and $\mathrm{B}$ lymphocytes and macrophage, thus blocking its interaction with PD-L1 and PD-L2 [43].

It has been approved by the EMA and FDAapproved to treat adult patients affected by locally advanced and metastatic cutaneous squamous cell carcinoma who are not suitable for surgery or radiotherapy and as firstline treatment for adult patients presenting with non-small-cell lung cancer (NSCLC) expressing PD-L1, with no EGFR, ALK or ROS1 [44].

Recently, it has also received EMA approval for the treatment of locally advanced or metastatic BCC not responding to $\mathrm{HH}$ pathway inhibitor.

Two open-label, multi-center, nonrandomized studies (Study 1423, $n=26$; Study 1540, $n=193$ [EMPOWER-CSCC 1]) involving 219 patients with mcSCC or lacSCC evaluated the efficacy and tolerability of cemiplimab [44]. In study 1423, 26 patients (mcSCC:16; lacSCC:10) were treated with cemiplimab $3 \mathrm{mg} / \mathrm{kg}$ intravenously every 2 weeks up to 48 weeks [44]. The incidence of treatment-emergent AEs was the primary objective to be evaluated. An ORR (complete response rate of $7.7 \%$ and partial response rate of $42.3 \%$ ) was reported in $50 \%$ of patients, whereas five patients reported stable disease (SD) and six presented progressive disease; two patients were not evaluable for response. A disease control rate of $65 \%$ and median time to response of 2.3 months (range: 1.7-7.3) were also reported.

The phase II trial EMPOWER-cSCC 1 had assessment of the ORR as primary objective [45]. One hundred ninety-three patients were enrolled and divided into three groups: group 1 ( $n=$ 59 patients) with mcSCC receiving cemiplimab $3 \mathrm{mg} / \mathrm{kg}$ every 2 weeks, group 2 ( $n=78$ patients) with lacSCC receiving $3 \mathrm{mg} / \mathrm{kg}$ biweekly and group 3 ( $n=56$ patients) with mcSCC receiving a dose of $350 \mathrm{mg}$ intravenously every 3 weeks [46].

A median time to response of 1.9 months was reported for group 1 and 2, whereas, a median time of 2.1 was described for group 3 . Interestingly, group 2 reported an ORR of $44 \%$ (CR: 13\%; PR: 31\%). Durable response for a period $\geq 6$ months was seen in $68 \%$ of patients. Regarding the other two cohorts of patients enrolled, Group 1 showed an ORR in $49 \%$ of patients and patients in group 3 reported an ORR of $41.1 \%[45,46]$. Finally, a multicenter, prospective, non-interventional phase IV trial, CASE (CemiplimAb-rwlc Survivorship and Epidemiology, NCT03836105), designed with the 
Table 2 Main features of the immune checkpoint inhibitors in clinical trials

\begin{tabular}{|c|c|c|c|c|c|c|c|}
\hline Drug & Dosage & Tumor & Study & Patients & TTR & ORR & $\mathbf{A E}$ \\
\hline $\begin{array}{l}\text { Cemiplimab } \\
\text { [44] }\end{array}$ & $\begin{array}{c}\text { Iv } 3 \mathrm{mg} / \mathrm{kg} \\
\text { Q2W }\end{array}$ & cSCC & Study 1423 & 26 & 2.3 months & $\begin{array}{l}13 \\
\quad(50.0 \%)\end{array}$ & $\begin{array}{l}\text { Fatigue } 7 \\
\quad(26.9 \%) \\
\text { Constipation } 4 \\
(15.4 \%) \\
\text { Decreased } \\
\text { appetite } 4 \\
(15.4 \%)\end{array}$ \\
\hline \multirow[t]{3}{*}{$\begin{array}{c}\text { Cemiplimab } \\
{[44-46]}\end{array}$} & $\begin{array}{c}\text { Iv } 3 \mathrm{mg} / \mathrm{kg} \\
\text { Q2W }\end{array}$ & mcSCC & $\begin{array}{l}\text { EMPOWER- } \\
\text { CSCC } 1 \text { (group } \\
\text { 1) }\end{array}$ & 59 & 1.9 months & $\begin{array}{l}29 \\
(49.2 \%)\end{array}$ & $\begin{array}{c}\text { Diarrhea } 16 \\
\qquad(27.1 \%) \\
\text { Fatigue } 14 \\
(23.7 \%) \\
\text { Nausea } 10 \\
(16.9 \%)\end{array}$ \\
\hline & $\begin{array}{c}\text { Iv } 3 \mathrm{mg} / \mathrm{kg} \\
\text { Q2W }\end{array}$ & lacSCC & $\begin{array}{l}\text { EMPOWER- } \\
\text { CSCC } 1 \\
\text { (group 2) }\end{array}$ & 78 & 1.9 months & $\begin{array}{l}34 \\
\quad(43.6 \%)\end{array}$ & $\begin{array}{c}\text { Fatigue } 32 \\
\quad(41.0 \%) \\
\text { Diarrhea } 21 \\
(26.9 \%) \\
\text { Pruritus } 21 \\
\text { (26.9\%) }\end{array}$ \\
\hline & $\begin{array}{c}\text { Iv } 350 \mathrm{mg} \\
\text { Q3W }\end{array}$ & mcSCC & $\begin{array}{l}\text { EMPOWER- } \\
\text { CSCC } 1 \\
\text { (group 3) }\end{array}$ & 56 & 2.1 months & $\begin{array}{l}23 \\
(41.1 \%)\end{array}$ & $\begin{array}{c}\text { Fatigue } 16 \\
\quad(28.6 \%) \\
\text { Diarrhea } 10 \\
(17.9 \%) \\
\text { Nausea } 10 \\
(17.9 \%)\end{array}$ \\
\hline $\begin{array}{l}\text { Cemiplimab } \\
{[50]}\end{array}$ & $\begin{array}{c}\text { Iv } 350 \mathrm{mg} \\
\text { Q3W }\end{array}$ & $\mathrm{BCC}$ & Phase II & 84 & 4.3 months & $\begin{array}{l}26 \\
\quad(31.0 \%)\end{array}$ & $\begin{array}{l}\text { Fatigue } 25 \\
\qquad(29.8 \%) \\
\text { Diarrhoea } 20 \\
(23.8 \%) \\
\text { Asthenua } 18 \\
(21.4 \%)\end{array}$ \\
\hline
\end{tabular}


Table 2 continued

\begin{tabular}{lcllclcc}
\hline Drug & Dosage & Tumor & Study & Patients & TTR & ORR & AE \\
\hline Pembrolizumab & Iv 200 mg & cSCC & KEYNOTE-629 & Total: 159 & 2.0 months & 40.3 & Pruritus 29 \\
[52] & Q3W & & & lacSCC: 54 & & lacSCC: & $(18.2 \%)$ \\
& & & & $(34.0 \%)$ & & 50.0 & Fatigue 23 \\
& & & & mcSCC: & mcSCC: & $(14.5 \%)$ \\
& & & & 105 & & 35.2 & Asthenia 20 \\
& & & & $(66.0 \%)$ & & & $(12.6 \%)$ \\
\hline
\end{tabular}

$T T R$ time to response, $O R R$ objective response ratio, $A E$ adverse event, $Q 2 W$ every 2 weeks, $Q 3 W$ every 3 weeks, $B C C$ basal cell carcinoma, $m c S C C$ metastatic cutaneous squamous cell carcinoma, lacSCC locally advanced cutaneous squamous cell carcinoma

aim of assessing several data from patients with lacSCC or mcSCC in treatment with cemiplimab at the labeled dosage (350 mg IV, Q3W) in a real-life experience, is still ongoing [47].

Data from real-life experiences confirmed the safety and the efficacy of cemiplimab in both locally advanced and metastatic CSCC, as assessed in clinical trials [48, 49].

Recently, an open-label, multicenter, nonrandomized Phase II trial, including 119 patients with laBCC or mBCC resistant or intolerant to $\mathrm{HH}$, evaluated the efficacy of endovenous cemiplimab $350 \mathrm{mg}$ every 3 weeks for up to 93 weeks [44]. Stratigos et al. [50] reported the results from 84 evaluable patients. Six showed CR, while PR was observed in 21 patients. Moreover, 82 (97.6\%) patients reported at least one $\mathrm{AE}$, with fatigue being the most frequently reported $(25,29.8 \%)$.

Although the reported trial showed the efficacy and safety of cemiplimab for the treatment of patients with advanced BCC, to date, only one case from real-life experience has already been described in the literature [51].

\section{Pembrolizumab}

Pemrbolizumab is a PD-1 inhibitor recently approved by the FDA for the treatment of patients with recurrent or metastatic cSCC not curable by radiation or surgery.

The efficacy and safety of pembrolizumab in cSCC have been evaluated in a multicenter, non-randomized, Phase II trial (KEYNOTE-629) evaluating 159 patients with locally advanced, metastatic or recurrent cSCC treated with endovenous infusions of $200 \mathrm{mg}$ pembrolizumab every 3 weeks. CR and PR were observed in 20 and 44 treated patients, respectively. One hundred ten patients reported drugrelated AEs with pruritus being the most represented one $(n=29)$ [52].

To date, there is only a limited investigatorinitiated, proof-of-concept study evaluating the efficacy and safety of pembrolizumab in patients with difficult-to-treat BCCs [53].

\section{Nivolumab and Ipilimumab}

Nivolumab and ipilimumab are two immune checkpoint inhibitors acting by blocking PD1 and cytotoxic T-lymphocyte-associated protein 4 (CTLA4), respectively. Even if these drugs are currently approved for melanoma [54, 55], in the literature there are only a few cases reporting their use in cSCC and/or BCC [56-59]. However, several multicenter trials evaluating their efficacy in treating advanced BCC and SCC are ongoing [60-64].

\section{DISCUSSION}

$\mathrm{KC}$ are the most frequent tumors in the Western world [1, 2], with an increasing incidence of both BCC and cSCC worldwide. Although surgery represent the gold-standard treatment for these tumors, sometimes they can progress to 
invasive forms, locally invading the underlying structures or metastatizing, thus requiring alternative options. In recent years, the challenging scenario of advanced and metastatic BCCs and cSCCs has changed with the introduction of new treatments. HH inhibitors (vismodegib and sonidegib) and the anti PD-1 cemiplimab are the therapeutic options already approved for the treatment of advanced BCCs and advanced cSCC, respectively [26, 43, 65].

Vismodegib and sonidegib act by inhibiting SMO receptor, thus blocking the $\mathrm{HH}$ signalling pathway, which has a key role in BCC pathogenesis. Several studies showed their efficacy in reducing tumor size up to complete regression of the disease $[19,25]$. Moreover, HH inhibitors could also be used in patients with Gorlin syndrome, as studies showed complete regression of BCC and absence of progressive disease in a large proportion of treated patients. Muscle spasms, dysgeusia, diarrhea, fatigue, weight loss and alopecia are the AEs most frequently reported during $\mathrm{HH}$ inhibitor treatment; the correct management of AEs and use of supportive care to reduce their intensity should be an important strategy to adopt to avoid treatment discontinuation. Among the new emerging $\mathrm{HH}$ inhibitors, patidegib and taladegib are two promising molecules whose efficacy and safety are undergoing clinical investigations, and further studies are still required $[32,38]$. In particular, topical formulation of patidegib could be a valid option for patients untreatable with oral HH inhibitors.

cSCC is the second cause of death from skin cancer, only preceded by melanoma, with an increasing worldwide incidence. Although most cSCCs are treated with surgery, $\leq 5 \%$ of patients may present with non-resectable disease, including locally advanced (lacSCC) or metastatic (mcSCC) disease [6]. The introduction of checkpoint inhibitors has revolutionized the therapeutic scenario of advanced cSSC. Targeting the PD-L1/PD-1 axis seems to be the new objective of several studies to allow the treatment of lacSCC and mcSCC. Although cemiplimab and pembrolizumab have been recently FDA approved for the treatment of locally advanced and metastatic cSCCs, different studies investigating the efficacy and safety of nivolumab and ipilimumab in treating these tumors are ongoing $[44,54,55]$. The effectiveness of cemiplimab has been reported in clinical trials with $>30 \%$ of patients achieving an ORR. Similarly, ORR was reached in $>40 \%$ of patients treated with pembrolizumab.

As for most targeted therapies, drug resistance represents a challenge; the development of new molecules targeting different proteins involved in the $\mathrm{HH}$ pathway or in the PD-L1/ PD-1 axis will allow overcoming resistance to treatment. Further data from clinical investigations and real-life experiences are still required to analyze the efficacy and tolerability of these drugs in the daily practice routine.

\section{ACKNOWLEDGEMENTS}

Funding. No funding or sponsorship was received for this study or publication of this article.

Authorship. All named authors meet the International Committee of Medical Journal Editors (ICMJE) criteria for authorship for this article, take responsibility for the integrity of the work as a whole, and have given their approval for this version to be published.

Author Contributions. Conception and design: Alessia Villani, Massimiliano Scalvenzi. Acquisition of data, analysis, and interpretation of data: Alessia Villani, Luca Potestio. Drafting the article: Alessia Villani, Gabriella Fabbrocini. Critical revision: Alessia Villani, Massimiliano Scalvenzi, Luca Potestio. Final approval of the version to be published: Alessia Villani, Massimiliano Scalvenzi, Gabriella Fabbrocini.

Disclosures. Alessia Villani, Luca Potestio, Gabriella Fabbrocini and Massimiliano Scalvenzi have nothing to disclose.

Compliance with Ethics Guidelines. This article is based on previously conducted studies and all human participants gave their written informed consent. 
Open Access. This article is licensed under a Creative Commons Attribution-NonCommercial 4.0 International License, which permits any non-commercial use, sharing, adaptation, distribution and reproduction in any medium or format, as long as you give appropriate credit to the original author(s) and the source, provide a link to the Creative Commons licence, and indicate if changes were made. The images or other third party material in this article are included in the article's Creative Commons licence, unless indicated otherwise in a credit line to the material. If material is not included in the article's Creative Commons licence and your intended use is not permitted by statutory regulation or exceeds the permitted use, you will need to obtain permission directly from the copyright holder. To view a copy of this licence, visit http:// creativecommons.org/licenses/by-nc/4.0/.

\section{REFERENCES}

1. Firnhaber JM. Basal cell and cutaneous squamous cell carcinomas: diagnosis and treatment. Am Fam Physician. 2020;102(6):339-46.

2. Nagarajan P, Asgari MM, Green AC, et al. Keratinocyte carcinomas: current concepts and future research priorities. Clin Cancer Res. 2019;25(8): 2379-91.

3. Cameron MC, Lee E, Hibler BP, et al. Basal cell carcinoma: epidemiology; pathophysiology; clinical and histological subtypes; and disease associations. J Am Acad Dermatol. 2019;80(2):303-17. (Epub ahead of print).

4. Kim DP, Kus KJB, Ruiz E. Basal cell carcinoma review. Hematol Oncol Clin N Am. 2019;33(1): $13-24$.

5. Waldman A, Schmults C. Cutaneous squamous cell carcinoma. Hematol Oncol Clin N Am. 2019;33(1): $1-12$.

6. Que SKT, Zwald FO, Schmults CD. Cutaneous squamous cell carcinoma: incidence, risk factors, diagnosis, and staging. J Am Acad Dermatol. 2018;78(2):237-47.

7. Nagarajan P, Ivan D. Cutaneous squamous cell carcinomas: focus on high-risk features and molecular alterations. Glob Dermatol. 2016;3: 359-65.

8. Thompson AK, Kelley BF, Prokop LJ, Murad MH, Baum CL. Risk factors for cutaneous squamous cell carcinoma recurrence, metastasis, and diseasespecific death: a systematic review and meta-analysis. JAMA Dermatol. 2016;152:419-28.

9. Leus AJG, Frie M, Haisma MS, et al. Treatment of keratinocyte carcinoma in elderly patients-a review of the current literature. J Eur Acad Dermatol Venereol. 2020;34(9):1932-43.

10. Peris K, Fargnoli MC, Garbe C, et al. Diagnosis and treatment of basal cell carcinoma: European consensus-based interdisciplinary guidelines. Eur J Cancer. 2019;118:10-34.

11. Claveau J, Archambault J, Ernst DS, et al. Multidisciplinary management of locally advanced and metastatic cutaneous squamous cell carcinoma. Curr Oncol. 2020;27(4):e399-407.

12. Stratigos AJ, Garbe C, Dessinioti C, et al. European interdisciplinary guideline on invasive squamous cell carcinoma of the skin: part 2. Treatment. Eur J Cancer. 2020;128:83-102.

13. Villani A, Cinelli E, Fabbrocini G, et al. Hedgehog inhibitors in the treatment of advanced basal cell carcinoma: risks and benefits. Expert Opin Drug Saf. 2020;19(12):1585-94.

14. Work Group; Invited Reviewers, Kim JYS, et al. Guidelines of care for the management of cutaneous squamous cell carcinoma. J Am Acad Dermatol. 2018;78(3):560-78.

15. Rimkus TK, Carpenter RL, Qasem S, Chan M, Lo $\mathrm{H}-\mathrm{W}$. Targeting the sonic hedgehog signaling pathway: review of smoothened and GLI inhibitors. Cancers (Basel). 2016;8(2):22.

16. Skoda AM, Simovic D, Karin V, Kardum V, Vranic S, Serman L. The role of the Hedgehog signaling pathway in cancer: a comprehensive review. Bosn J Basic Med Sci. 2018;18(1):8-20.

17. Pak E, Segal RA. Hedgehog signal transduction: key players, oncogenic drivers, and cancer therapy. Dev Cell. 2016;38(4):333-44.

18. Gutzmer R, Solomon JA. Hedgehog pathway inhibition for the treatment of basal cell carcinoma. Target Oncol. 2019;14(3):253-67.

19. European Medicines Agency. Everidge (vismodegib): summary of product characteristics. 2013. Available from: European Medicines Agency. Everidge (vismodegib): summary of product characteristics. 2013. Accessed on 18 Sep 2021. 
20. LoRusso PM, Rudin CM, Reddy JC, et al. Phase I trial of hedgehog pathway inhibitor vismodegib (GDC0449) in patients with refractory, locally advanced or metastatic solid tumors. Clin Cancer Res. 2011;17(8):2502-11.

21. Sekulic A, Migden MR, Basset-Seguin N, et al. Longterm safety and efficacy of vismodegib in patients with advanced basal cell carcinoma: final update of the pivotal ERIVANCE BCC study. BMC Cancer. 2019;19(1):366.

22. Dréno B, Kunstfeld R, Hauschild A, et al. Two intermittent vismodegib dosing regimens in patients with multiple basal-cell carcinomas (MIKIE): a randomised, regimen-controlled, doubleblind, phase 2 trial. Lancet Oncol. 2017;18(3): 404-12.

23. Basset-Séguin N, Hauschild A, Kunstfeld R, et al. Vismodegib in patients with advanced basal cell carcinoma: primary analysis of STEVIE, an international, open-label trial. Eur J Cancer. 2017;86: 334-48.

24. Villani A, Megna M, Fabbrocini G, Cappello M, Luciano MA, Costa C, Scalvenzi M. Long-term efficacy of vismodegib after its withdrawal and patients' health-related quality of life using the Dermatology Life Quality Index (DLQI). Dermatol Ther (Heidelb). 2019;9(4):719-24.

25. European Medicines Agency. Odomzo (sonidegib): summary of product characteristics. 2015. https:// www.ema.europa.eu/en/documents/product-infor mation/odomzo-epar-product-information_en.pdf Accessed 15 Sep 2021.

26. Villani A, Fabbrocini G, Costa C, et al. Expert opinion on sonidegib efficacy, safety and tolerability. Expert Opin Drug Saf. 2021;20(8):877-82.

27. Villani A, Fabbrocini G, Costa C, et al. Sonidegib: safety and efficacy in treatment of advanced basal cell carcinoma. Dermatol Ther (Heidelb). 2020;10(3):401-12.

28. Migden MR, Guminski A, Gutzmer R, et al. Treatment with two different doses of sonidegib in patients with locally advanced or metastatic basal cell carcinoma (BOLT): a multicentre, randomised, double-blind phase 2 trial. Lancet Oncol. 2015;16(6):716-28.

29. Chen L, Silapunt S, Migden MR. Sonidegib for the treatment of advanced basal cell carcinoma: a comprehensive review of sonidegib and the BOLT trial with 12-month update. Future Oncol. 2016;12(18):2095-105.

30. Lear JT, Migden MR, Lewis KD, et al. Long-term efficacy and safety of sonidegib in patients with locally advanced and metastatic basal cell carcinoma: 30-month analysis of the randomized phase 2 BOLT study. J Eur Acad Dermatol Venereol. 2018;32(3):372-81.

31. Dummer R, Guminksi A, Gutzmer R, et al. Longterm efficacy and safety of sonidegib in patients with advanced basal cell carcinoma: 42-month analysis of the phase II randomized, double-blind BOLT study. Br J Dermatol. 2020;182(6):1369-78.

32. Jimeno A, Weiss GJ, Miller WH Jr, et al. Phase I study of the Hedgehog pathway inhibitor IPI-926 in adult patients with solid tumors. Clin Cancer Res. 2013;19(10):2766-74.

33. Epstein EH, Lear J, Saldanha G, Tang JY, Harwood C. Hedge-hog pathway inhibition by topical patidegib to reduce BCC burden in patients with basal cell nevus (Gorlin) syndrome. J Clin Oncol. 2018;36(15_Supll.): e21626-e.

34. ClinicalTrials.gov. Trial of Patidegib Gel 2\%, 4\%, and Vehicle to Decrease the Number of Surgically Eligible Basal Cell Carcinomas in Gorlin Syndrome Patie. https://clinicaltrials.gov/ct2/show/results/NCT0 2762084 ? cond $=$ patidegib\&draw $=2 \&$ rank $=4$. Accessed 15 Sep 2021.

35. Ernst D. Patidegib gets breakthrough and orphan designation for Gorlin syndrome. 2017. https:// www.empr.com/patidegib-gets-breakthrough-andorphan-designation-for-gorlin-syndrome/printarti cle/708449/. Accessed 6 Feb 2018.

36. ClinicalTrials.gov. Clinical Trial of Patidegib Gel 2\%, $4 \%$, and vehicle applied once or twice daily to decrease the GLI1 biomarker in sporadic nodular basal cell carcinomas (BCC). https://clinicaltrials. gov/ct2/show/results/NCT02828111?cond=patideg ib\&draw=2\&rank=5. Accessed 15 Sep 2021.

37. ClinicalTrials.gov. Extension Study of Patidegib Topical Gel, 2\% in subjects with gorlin syndrome (basal cell nevus syndrome). https://clinicaltrials. gov/ct2/show/record/NCT04308395?cond=patideg ib\&draw=2\&rank=1. Accessed 15 Sep 2021.

38. Bendell J, Andre V, Ho A, et al. Phase I study of LY2940680, a Smo antagonist, in patients with advanced cancer including treatment-naïve and previously treated basal cell carcinoma. Clin Cancer Res. 2018;24(9):2082-91.

39. Ueno H, Kondo S, Yoshikawa S, et al. A phase I and pharmacokinetic study of taladegib, a smoothened inhibitor, in Japanese patients with advanced solid tumors. Invest New Drugs. 2018;36(4):647-56.

40. Jin G, Sivaraman A, Lee K. Development of taladegib as a sonic hedgehog signaling pathway inhibitor. Arch Pharm Res. 2017;40(12):1390-3. 
41. Rischin D, Migden MR, Lim AM, Schmults CD, Khushalani NI, Hughes BGM, et al. Phase 2 study of cemiplimab in patients with metastatic cutaneous squamous cell carcinoma: primary analysis of fixeddosing, long-term outcome of weight-based dosing. J Immunother Cancer. 2020;8: e000775. (Epub ahead of print).

42. Lipson EJ, Lilo MT, Ogurtsova A, et al. Basal cell carcinoma: PD-L1/PD-1 checkpoint expression and tumor regression after PD-1 blockade. J Immunother Cancer. 2017;5:23 (Published 2017 Mar 21).

43. Villani A, Ocampo-Garza SS, Potestio L, et al. Cemiplimab for the treatment of advanced cutaneous squamous cell carcinoma. Expert Opin Drug Saf. 2021:1-9. (Epub ahead of print).

44. LIBTAYO, Summary of product characteristics. https://www.ema.europa.eu/en/documents/prod uct-information/libtayo-epar-product-information en.pdf. Accessed 18 Sep 2021.

45. Owonikoko TK, Papadopoulos KP, Johnson ML. Phase I study of cemiplimab, a human monoclonal anti-PD-1, in patients with unresectable locally advanced or metastatic cutaneous squamous cell carcinoma (CSCC): longer follow-up efficacy and safety data. Ann Oncol. 2018. https://doi.org/10. 1093/annonc/mdy487.002.

46. Migden MR, Khushalani NI, Chang ALS, Lewis KD, Chrysalyne D, Hernandez-aya L, et al. Cemiplimab in locally advanced cutaneous squamous cell carcinoma: results from an open-label, phase 2, singlearm trial. Lancet Oncol. 2021;21(2):294-305. (Epub ahead of print).

47. Migden MR, Chandra S, Rabinowits G, Chen CI, Desai J, Seluzhytsky A, et al. CASE (CemiplimAbrwlc Survivorship and Epidemiology) study in advanced cutaneous squamous cell carcinoma. Future Oncol. 2020;16(4):11-9.

48. Guillaume T, Puzenat E, Popescu D, Aubin F, Nardin C. Cemiplimab-rwlc in advanced cutaneous squamous cell carcinoma: a real-life experience in a French dermatology department. Br J Dermatol. 2021;1. (Epub ahead of print).

49. Tsung I, Worden FP, Fontana RJ. A pilot study of checkpoint inhibitors in solid organ transplant recipients with metastatic cutaneous squamous cell carcinoma. Oncologist. 2021;26(2):133-8.

50. Stratigos AJ, Sekulic A, Peris K, et al. Cemiplimab in locally advanced basal cell carcinoma after hedgehog inhibitor therapy: an open-label, multi-centre, single-arm, phase 2 trial. Lancet Oncol. 2021;22(6): 848-57.
51. Dumann K, Artz N, Ziemer M. Complete remission of basal cell carcinoma following treatment with cemiplimab after 2 years. JAMA Dermatol. 2021;157(8):1004-6.

52. Hughes BGM, Munoz-Couselo E, Mortier L, et al. Pembrolizumab for locally advanced and recurrent/ metastatic cutaneous squamous cell carcinoma (KEYNOTE-629 study): an open-label, nonrandomized, multicenter, phase II trial. Ann Oncol. 2021;32(10):1276-85.

53. Chang ALS, Tran DC, Cannon JGD, et al. Pembrolizumab for advanced basal cell carcinoma: an investigator-initiated, proof-of-concept study. J Am Acad Dermatol. 2019;80(2):564-6.

54. Opdivo. Summary of product characteristics. https://www.ema.europa.eu/en/documents/prod uct-information/opdivo-epar-product-information en.pdf. Accessed 18 Sep 2021.

55. YERVOY. Summary of product characteristics. https://www.ema.europa.eu/en/documents/smop/ chmp-post-authorisation-summary-positive-opini on-yervoy-ws-1278_en.pdf. Accessed 18 Sep 2021.

56. Mohan SV, Kuo KY, Chang AL. Incidental regression of an advanced basal cell carcinoma after ipilimumab exposure for metastatic melanoma. JAAD Case Rep. 2016;2(1):13-5 (Published 2016 Jan 8).

57. Barrios DM, Do MH, Phillips GS, et al. Immune checkpoint inhibitors to treat cutaneous malignancies. J Am Acad Dermatol. 2020;83(5):1239-53.

58. Oro-Ayude M, Suh-Oh HJ, Sacristán-Santos V, Vázquez-Bartolomé P, Flórez Á. Nivolumab for metastatic cutaneous squamous cell carcinoma. Case Rep Dermatol. 2020;12(1):37-41 (Published 2020 Feb 12).

59. Blum V, Müller B, Hofer S, et al. Nivolumab for recurrent cutaneous squamous cell carcinoma: three cases. Eur J Dermatol. 2018;28(1):78-81.

60. ClinicalTrials.gov. Nivolumab alone or plus relatlimab or ipilimumab for patients with locally-advanced unresectable or metastatic basal cell carcinoma. https://clinicaltrials.gov/ct2/show/ NCT03521830?cond=nivolumab + basal + cell + car cinoma\&draw=2\&rank=1. Accessed 14 Sep 2021.

61. ClinicalTrials.gov. Nivolumab with vismodegib in patients with basal cell nevus syndrome. https:// clinicaltrials.gov/ct2/show/NCT03767439?cond= nivolumab+basal+cell+carcinoma\&draw $=2 \&$ ran k=5. Accessed 14 Sep 2021 .

62. ClinicalTrials.gov. Neo-adjuvant nivolumab or nivolumab with ipilimumab in advanced cutaneous squamous cell carcinoma prior to surgery 
(MATISSE). https://clinicaltrials.gov/ct2/show/NCT 04620200? cond=nivolumab+cutaneous + squam ous + cell + carcinoma\&draw $=2 \&$ rank $=1$. Accessed 16 Sep 2021.

63. ClinicalTrials.gov. Nivolumab in patients with advanced cutaneous squamous cell carcinoma (CA209-9JC). https://clinicaltrials.gov/ct2/show/ NCT03834233?cond=nivolumab + cutaneous + squa mous + cell + carcinoma\&draw $=2 \&$ rank $=2$. Accessed 15 Sep 2021.
64. ClinicalTrials.gov. Nivolumab for treatment of squamous cell carcinoma of the skin. https:// clinicaltrials.gov/ct2/show/NCT04204837?cond= nivolumab+cutaneous+squamous+cell+carcin oma\&draw=2\&rank=3. Accessed 18 Sep 2021.

65. Villani A, Fabbrocini G, Cappello M, et al. Real-life effectiveness of vismodegib in patients with metastatic and advanced basal cell carcinoma: characterization of adverse events and assessment of health-related quality of life using the Dermatology Life Quality Index (DLQI) Test. Dermatol Ther (Heidelb). 2019;9(3):505-10. 